\title{
PENGARUH GLOBALISASI EKONOMI DAN HUKUM EKONOMI INTERNASIONAL DALAM PEMBANGUNAN HUKUM EKONOMI DI INDONESIA
}

\section{SHIDQON PRABOWO}

Dosen Fakultas Hukum Universitas Wahid Hasyim Semarang, jl. Menoreh Tengah X/22 Sampangan Semarang, Telp: 024-8505680,Hp: 081228666685,E-mail: Kajine_Belink@yahoo.com

\begin{abstract}
ABSTRAK
Tipikal negara berkembang ditandai dengan adanya transformasi dari masyarakat buruh menjadi masyarakat madani dan hal ini berpengaruh pada peran hukum itu sendiri. Berbagai masalah akan timbul pada negara dunia ketiga seperti pendidikan, budaya, kesejahteraan dan hukum. Sementara itu, perkembangan ekonomi bergantung pada hal-hal esensial seperti prediktabilitas, kemampuan prosedural, codification against goals, keseimbangan akomodasi dan definisi status. Perjalanan pembangunan ekonomi Indonesia pada era Orde Baru yang mengesankan terjadinya peningkatan kesejahteraan secara berkelanjutan dan bertahap, telah menjadikan harapan bagi masyarakat menengah ke bawah. Akan tetapi, pada prospek jangka panjang justru menyisakan tangisan dan penderitaan ekonomi secara sistemik. Hal ini dapat dilihat dari krisis moneter yang bergejolak pada tahun 1998. Perkembangan Ekonomi di suatu negara tidak terlepas dari kebijakan hukum baik dalam negeri maupun luar negeri dan pengaruh arus deras globalisasi. Melalui pendekatan progresif inilah analisis pembangunan hukum ekonomi dikaji lebih mendalam.
\end{abstract}

Kata Kunci: Pembangunan Ekonomi, Progresif.

\begin{abstract}
A developed country typically signed by transformation from manufacturing society to service society and it will influenced the role of law. Many problem will be faced in the third world such as education, cultural, welfare and law enforcement. Meanwhile, economic development depends on essensial items such as predictability, procedural ability, codification against goals, balance of akomodation dan definition status. Indonesian economic development in new orde era that impressed an increasing level of prosperity continously makes lowfare society hopes a lot. But in the long term prospect, it will make an economic suffer in a sistemic way. This can be seen as a moneteric crisis in the 1998. Economic development in a country will never be happened without law policy whether in the domestic and foreign country as well as from rapid influence globalisation era. Through the progressive approach, law economic development analisis will be deeply studied for furthermore.
\end{abstract}

Keyword : Economic development, Progressive.

Copyright (C) 2015, LITIGASI, p-ISSN: 0853-7100; e-ISSN: 2442-2274 
Available online at: http://ejournal.unpas.ac.id/index.php/litigasi

Litigasi, Vol. 16(1), 2015, 2741-2780

DOI: http://dx.doi.org/10.23969/litigasi.v16i1.52

\section{PENDAHULUAN}

Semenjak krisis ekonomi melanda pada tahun 1997-1998, pertumbuhan ekonomi di Indonesia sangat memprihatinkan, bahkan ada yang mengatakan lambat atau rendah, yang dampaknya ketimpangan pendapatan diantara masyarakat yang sudah rentan dimana sebagian kecil masyarakat mempunyai pendapatan yang sangat tinggi sedangkan sebagian besar masyarakat hidup dibawah garis kemiskinan (Diana Halim Koentjoro, 2006). Dalam lintasan sejarah, pembangunan sebagai sebuah upaya penataan ekonomi sebuah negara dapat ditelusuri dalam kurun waktu yang lama. Bahkan pemikiran-pemikiran Adam Smith yang disusun sejak abad ke-18 masih dijadikan rujukan bagi pembangunan ekonomi saat ini, khususnya negara-negara maju yang mengidentifikasi ekonominya sebagai mazhab kapitalis. Tetapi dalam penyelenggaraannya, proyek pembangunan sempat terhenti akibat Perang Dunia II yang melantakan sebagian besar negara, terutama negara-negara Eropa. Setelah Perang Dunia II itulah, Eropa yang hancur lebur akibat perang, dengan sendirinya memerlukan pembangunan untuk menata kembali perekonomiannya. Instrumen pembangunan (atau tepatnya rekonstruksi) ini adalah program bantuan besarbesaran dari Amerika Serikat, yakni Marshal Aid. Program ini memiliki tujuan ganda, untuk menjalankan ekonomi dunia dan menahan laju komunisme (Ahmad Erani Yustika, 2002).

Copyright $\odot$ 2015, LITIGASI, p-ISSN: 0853-7100; e-ISSN: 2442-2274 
Available online at: http://ejournal.unpas.ac.id/index.php/litigasi

Litigasi, Vol. 16(1), 2015, 2741-2780

DOI: http://dx.doi.org/10.23969/litigasi.v16i1.52

Tampak sejak awal gagasan pembangunan yang mulai marak dijalankan setelah Perang Dunia II itu memiliki tujuan penting, khususnya lewat program Marshal Aid, pertama, pembangunan dipakai sebagai alat untuk menyebarkan tata ekonomi tunggal dunia, dimana model ini mendasarkan diri pada mekanisme pasar dan liberalisasi perdagangan. Kedua, pembangunan juga memiliki tujuan politis untuk menahan perluasan ide dan penerapan komunisme yang dianggap membahayakan kepentingan negara kapitalisme (Ahmad Erani Yustika, 2002).

Proyek pembangunan setelah Perang Dunia II sarat dengan capaian-capaian material dalam bidang ekonomi. Pembangunan dilukiskan sebagai sebuah proses menuju kemajuan material perekonomian, sehingga ukuran-ukuran keberhasilannya dilihat dari indikator semacam pertumbuhan akumulasi investasi dan tingkat konsumsi masyarakat. Dengan karakteristik semacam itu, negaranegara yang memiliki akumulasi modal dan ketahanan ekonomi yang mapan, akan semakin melakukan ekspansi ekonomi ke tiap-tiap negara yang berada pada zona Dunia Ketiga. Istilah Dunia Ketiga lebih diartikan sebagai negara-negara yang secara ekonomi masih miskin, atau negara-negara yang sedang berkembang. Konsep pembangunan Dunia Ketiga tentunya memiliki tingkat harapan tersendiri dalam memenuhi sektor pembangunan ekonominya, sehingga tidak dapat disetarakan dengan negara adikuasa yang telah berkembang dalam segala aspek.

Bagi negara-negara Dunia Ketiga, persoalannya adalah bagaimana bertahan hidup, atau bagaimana meletakkan dasar-dasar ekonominya supaya bisa bersaing

Copyright $\odot$ 2015, LITIGASI, p-ISSN: 0853-7100; e-ISSN: 2442-2274 
di pasar internasional; sementara negara-negara adikuasa persoalannya adalah bagaimana secara sistematis dapat melakukan ekspansi lebih lanjut bagi kehidupan ekonominya yang sudah mapan (Arief Budiman, 1995). Sehingga filsafat pembangunan seperti ini kerap disebut dengan istilah "fordisme", yang merujuk kepada upaya terciptanya masyarakat dunia yang makmur berdasarkan maksimasi kegunaan tanpa batas, yang dibentuk melalui tiga elemen penting, yaitu rasionalitas, efisiensi, dan produksi/konsumsi massal (Arief Budiman, 1995).

Tidak dapat dipungkiri filsafat pembangunan ekonomi Indonesia dalam pandangan dunia internasional, bahwa Indonesia menjadi perhitungan negara yang sedang berkembang serta identik dengan zona Dunia Ketiga. Pelaksanaan pembangunan ekonomi Indonesia era Orde Baru memang cukup banyak mendatangkan perubahan. Salah satu diantaranya adalah dalam bentuk peningkatan pendapatan per kapita nasional. Bila pada tahun 1969 pendapatan per kapita Indonesia baru mencapai US\$ 70, maka berkat pertumbuhan ekonomi yang rata-rata mencapai 6,5 persen per tahun, pada tahun 1995 angka itu telah meningkat menjadi sekitar US\$ 880, atau sekitar Rp. 2 juta per orang per tahun. Sejalan perkembangan waktu pendapatan pada sektor pertanian, jasa dan industri semakin seimbang (Revirsond Baswir, 2004). Tetapi bila dikaji lebih jauh, perjalan pembangunan ekonomi Indonesia pada era Orde Baru yang mengesankan telah terjadinya peningkatan kesejahteraan secara berarti, namun pada prospek jangka panjang menyisakan tangisan dan penderitaan ekonomi secara sistemik. Hal ini dapat dilihat krisis moneter yang bergejolak pada 
tahun 1998, serta diikuti dengan instabilitas politik menjadikan Indonesia negara yang mengalami krisis berkepanjangan dan sampai hari ini dapat dirasakan dampak dari pembangunan ekonomi di bawah rezim Orde Baru. Salah satunya ialah negara ini dipaksa melakukan penyesuaian dengan mekanisme pasar terhadap kenaikan harga minyak dunia. Tak heran ketika setiap waktu harga BBM (bahan bakar minyak) akan selalu naik, disamping Indonesia saat ini bukan lagi sebagai negara eksportir minyak, di lain hal sistem perekonomian yang masih terkesan hanya mengikuti poros mekanisme pasar, tanpa ada kontrol yang akuratif. Alhasil mental negara ini menjadi rapuh, kesenjangan sosial makin terlihat tanpa batas, tingkat kriminalitas tiap tahun meningkat, serta yang lebih ironis lagi ketahanan pangan menjadi problem yang selalu menghantui.

Suatu bangsa dikategorikan pertumbuhan ekonomi baik salah satunya bilamana ada peningkatan secara signifikan pada pendapatan perkapita rakyatnya dan memperkecil ketergantungan pada hutang luar negeri. Menurut Organs Ski's pembangunan suatu bangsa sedikitnya harus melalui tiga tahap, diantaranya: pertama, politik unifikasi, kedua politik industrialisasi, dan ketiga, politik kesejahteraan sosial (Hasnati, 2004).

Seharusnya hukum berperan untuk mengerakkan masyarakat menuju perubahan yang terencana. Disini hukum berperan aktif sebagai alat untuk rekayasa sosial (law as a tool of social engineering). Artinya hukum dalam bidang kehidupan yang nyata harus lebih difungsikan sebagai sarana sosial kontrol dalam kehidupan masyarakat (Abdul Manan, 2006). Jika asumsi pembangunan 
Available online at: http://ejournal.unpas.ac.id/index.php/litigasi

Litigasi, Vol. 16(1), 2015, 2741-2780

DOI: http://dx.doi.org/10.23969/litigasi.v16i1.52

ekonomi Dunia Ketiga khususnya Indonesia disandarkan pada paradigma hukum progresif yang implementasinya responsif dan mendatangkan kemanfaatan sosial, tentunya alur berfikir pembangunan ekonomi Indonesia tidak serumit saat ini.

Tidak dapat dinafikan hukum progresif bukan instrumen ilmu ekonomi secara murni, akan tetapi prospek pembangunan ekonomi tentunya tidak terlepas dari mekanisme hukum dalam melakukan aktivitas ekonomi, yang hasil akhirnya dalam aspek hukum dapat memenuhi nilai kepastian, keadilan dan kemanfaatan. Maka paradigma hukum progresif dapat dijadikan batas apresiasi terhadap dinamika perkembangan arus globalisasi yang tidak saja terjadi pada sektor ekonomi dan tekhnologi, melainkan juga pada batas-batas tertentu, dan setiap negara terpaksa mengikuti arus globalisasi hukum sebagai bentuk penyesuaian terhadap pembangunan ekonomi melalui tujuan mekanisme pasar dan perdagangan internasional. Kemudian timbul suatu pertanyaan bagaimana fungsi dan perkembangan hukum dalam pembangunan? Bagaimana arus globalisasi dan masa depan pembangunan ekonomi dunia ketiga? Bagaimana Pengaruh Globalisasi Ekonomi dan Hukum Ekonomi Internasional dalam Pembangunan Hukum Ekonomi di Indonesia? Dimana peran hukum sebagai bentuk perwujudan instrumen regulasi dalam pembangunan ekonomi Indonesia? 
Available online at: http://ejournal.unpas.ac.id/index.php/litigasi

Litigasi, Vol. 16(1), 2015, 2741-2780

DOI: http://dx.doi.org/10.23969/litigasi.v16i1.52

\section{PEMBAHASAN}

\section{A. Fungsi dan Perkembangan Hukum Dalam Pembangunan}

Hakekat pembangunan Indonesia adalah amanat konstitusi yang sesuai dengan ikrar dan cita-cita bangsa. Secara ideologis makna pembangunan negara ini ialah Pancasila, yang dapat diartikan pembangunan adalah membangun bangsa Indonesia seutuhnya, serta strategi pembangunan ialah pertumbuhan ekonomi, pemerataan kesejahteraan sosial, serta stabilitas politik. Kemudian lebih lanjut ditegaskan secara eksplisit pada alinea keempat Pembukaan UUD 1945 bahwa; hakikat pembangunan nasional adalah mencerdaskan kehidupan bangsa, menciptakan kesejahteraan umum, melindungi seluruh tumpah darah Indonesia, dan membantu melaksanakan ketertiban dunia, perdamaian abadi dan keadilan sosial.

Berdasarkan garis amanah konstitusi, maka makna pembangunan nasional harus mampu mereduksi nilai keseimbangan pada setiap aspek kehidupan sosial masyarakat. Sejak awal bangsa ini dihadapkan dengan tanggung jawab yang begitu besar, yaitu meneruskan perjuangan pasca penjajahan kolonialisme dalam bentuk pembangunan nasional pada setiap dimensi sosial masyarakat. Akan tetapi persoalannya apakah amanah yang mulia ini dapat begitu saja dijalankan dengan mudah. Mungkin hal ini tidak perlu dijawab, karena realitas kehidupan saat ini dapat menggambarkan potret Indonesia dalam menjalankan program pembangunan nasional pasca merdeka dari penjajahan tahun 1945.

Copyright @ $\odot$ 2015, LITIGASI, p-ISSN: 0853-7100; e-ISSN: 2442-2274 
Available online at: http://ejournal.unpas.ac.id/index.php/litigasi

Litigasi, Vol. 16(1), 2015, 2741-2780

DOI: http://dx.doi.org/10.23969/litigasi.v16i1.52

Setidaknya dapat dijelaskan secara umum ada beberapa tahapan atau tingkatan pembangunan yang dialami oleh suatu negara mulai dari negara berkembang sampai menjadi negara maju, yaitu tahap pertama, unifikasi dengan titik berat bagaimana mencapai integrasi politik untuk menciptakan persatuan dan kesatuan nasional, tahap kedua industrialisasi dengan fokus terhadap aktivitas pembangunan ekonomi dan modernisasi politik, kemudian tahap ketiga negara kesejahteraan dimana tugas negara terutama adalah perlindungan masyarakat dan kesejahteraan masyarakat (Erman Rajagukguk, 2005).

Program pembangunan suatu negara yang baik adalah pembangunan yang dilakukan secara komprehensif. Artinya, pembangunan selain mengejar pertumbuhan ekonomi semata, juga harus memperhatikan pelaksanaan jaminan perlindungan hak-hak asasi manusia warga negaranya yang telah diatur dalam konstitusi negara yang bersangkutan, baik hak-hak sipil, maupun hak ekonomi, sosial dan budaya. Dengan demikian, pembangunan yang telah, sedang dan akan dilakukan oleh pemerintah akan mampu menarik lahirnya partisipasi masyarakat dalam pembangunan. Arah pembangunan di Indonesia merupakan kegiatan yang terpadu, karena arah pembangunan itu adalah menciptakan pemerataan dan keadilan sosial. Oleh sebab itu interaksi pembangunan hukum dan pembangunan ekonomi sangat penting dan peranan ahli hukum dalam pembangunan ekonomi-pun menjadi unsur mutlak harus ada (Indra Afrita, 2005).

Copyright $\odot$ 2015, LITIGASI, p-ISSN: 0853-7100; e-ISSN: 2442-2274 
Available online at: http://ejournal.unpas.ac.id/index.php/litigasi

Litigasi, Vol. 16(1), 2015, 2741-2780

DOI: http://dx.doi.org/10.23969/litigasi.v16i1.52

Berdasarkan berbagai studi mengenai hukum dan pembangunan dapat diketahui, setidaknnya program pembangunan harus memenuhi kualitas hukum yang kondusif bagi perencanaan dan pelaksanaannya, yaitu stabilitas (stability), kalkulasi yang terencana (predictability), keadilan (fairness), pendidikan (education), dan pengembangan profesi hukum (the special development abilities of the lawyer) (Leonard J. Theberge, 1989). Stabilitas dan predictability adalah merupakan prasyarat untuk berfungsinya sistem ekonomi. Predictability sangat berperan, terutama bagi negara-negara yang masyarakatnya baru memasuki hubungan-hubungan ekonomi melintasi lingkungan sosial tradisional mereka. Sedangkan prasyarat stabilitas berarti hukum berpotensi dan dapat menjaga keseimbangan kepentingan-kepentingan yang saling bersaing. Aspek keadilan akan tercermin dari proses hukum, persamaan dihadapan hukum, dan standar sikap/perlakuan pemerintah, dan lain-lain akan mempengaruhi kelangsungan mekanisme pasar dan mencegah campur tangan pemerintah yang terlalu dominan (Leonard ], Theberge, 1989). Sedangkan pendidikan dan pengembangan profesi hukum merupakan sesuatu keharusan yang harus diberdayakan dalam praktek hukum, agar dapat berperan sebagai ahli hukum dalam pembangunan hukum dan pembangunan ekonomi.

Berbicara mengenai fungsi dan perkembangan hukum dalam pembangunan ekonomi suatu negara pada dasarnya tidak terlepas dari pembicaraan mengenai pendekatan ekonomi terhadap hukum atau sebaliknya,

Copyright @ C 2015, LITIGASI, p-ISSN: 0853-7100; e-ISSN: 2442-2274 
Available online at: http://ejournal.unpas.ac.id/index.php/litigasi

Litigasi, Vol. 16(1), 2015, 2741-2780

DOI: http://dx.doi.org/10.23969/litigasi.v16i1.52

pendekatan hukum terhadap ekonomi, yang lazim dikenal dengan analisis ekonomi terhadap hukum. Salah satu contoh konkrit bahwa adanya elaborasi keilmuan antar dua displin ilmu ekonomi dan hukum, ialah daya paksa arus globalisasi ekonomi yang memaksa instrumen hukum sebagai regulasi mekanisme ekonomi menyesuaikan diri terhadap perkembangan internasional, hal ini sering disebut dengan globalisasi hukum. Sehingga materi muatan berbagai undang-undang dan perjanjian-perjanjian sebagai sumber hukum positif harus mengadopsi kaedah-kaedah dan diharmonisasikan dengan ketentuan-ketentuan internasional yang bersifat lintas dan melewati batas-batas negara, yang dilakukan melalui ratifikasi perjanjian-perjanian dan konvensikonvensi serta kovenan-kovenan internasional, maupun hubungan-hubungan dan perjanjian privat serta institusi-institusi ekonomi baru.

Pendekatan hukum ekonomi bersifat dan menggunakan pendekatanpendekatan transnasional dan interdisipliner, dengan mengkhususkan diri pada hubungan - hubungan antara masalah - masalah ekonomi dan sosial nasional dan regional serta internasional secara integral. Atau dengan perkataan lain, pengaturan bidang-bidang hukum ekonomi harus selaras dengan arah dan kebijakan politik ekonomi pembangunan dan politik hukum pembangunan serta politik pembangunan masyarakat secara intern dan transdisipliner secara holistik dan sistematik (Hikmahanto Juwana, 2001). Sehingga dapat dikatakan bahwa ruang lingkup bidang hukum ekonomi (economic law) merupakan bidang hukum yang luas dan berkaitan dengan kepentingan privat dan 
Available online at: http://ejournal.unpas.ac.id/index.php/litigasi

Litigasi, Vol. 16(1), 2015, 2741-2780

DOI: http://dx.doi.org/10.23969/litigasi.v16i1.52

kepentingan umum (public interest) sekaligus. Untuk itu pendekatan ekonomi terhadap hukum, akan menjadi salah satu cara agar tidak terjadi ketertinggalan hukum dalam lalu lintas ekonomi dalam dan antar negara dengan negara lainnya baik secara nasional, regional dan internasional (Indra Afrita, 2005). Maka fungsi dan peran hukum dalam pembangunan dalam tahap legislasi nasional dimasa mendatang perlu memberikan prioritas pada undang-undang yang berkaitan dengan akumulasi modal untuk pembiayaan pembangunan dan demokratisasi ekonomi untuk mencapai efisiensi, memenuhi fungsi hukum sebagai fasilitator bisnis.

Oleh karenanya ahli hukum yang terlibat sebagai pembuat undangundang harus mampu memadukan studi hukum dengan disiplin ilmu lainnya secara komprehensif, agar tertib sosial bagi berfungsinya hukum karena terjadinya perubahan sosial dan tata pergaulan antar kelompok masyarakat, negara, antar negara, baik itu taraf nasional, regional dan internasional yang dalam prosesnya dapat berjalan secara responsif terhadap prinsip keseimbangan kepentingan pembangunan yang progresif.

B. Arus Globalisasi \& Masa Depan Pembangunan Ekonomi Dunia Ketiga

Revolusi industri dianggap sebagai tonggak lahirnya ekonomi global, yang tidak lagi memisahkan teori ekonomi sebagai acuan regulasi perekonomian negara. Teori ekonomi diposisikan hanya sebagai saksi perasan pemikiran sejarah yang dapat dilihat pada pasca Perang Dunia II dan berbagai

Copyright $\odot$ 2015, LITIGASI, p-ISSN: 0853-7100; e-ISSN: 2442-2274 
Available online at: http://ejournal.unpas.ac.id/index.php/litigasi

Litigasi, Vol. 16(1), 2015, 2741-2780

DOI: http://dx.doi.org/10.23969/litigasi.v16i1.52

keadaan yang berubah cepat, terutama dalam bidang perekonomian dunia yang menghilangkan sekat negara, bangsa serta kewilayahan. Revolusi teknologi informasi juga merupakan faktor pendukung utama perekonomian global atau biasa kita kenal dengan globalisasi. Globalisasi, khususnya dalam bidang ekonomi merupakan keniscayaan yang mau tidak mau harus direspon dengan baik oleh negara maupun pelaku ekonomi itu sendiri. Kondisi emperis ini, mengindikasikan bahwa harmonisasi hukum, khususnya yang mengatur aktivitas ekonomi, bukan hanya menjadi kebutuhan, tetapi juga telah menjadi prasyarat fungsional agar institusi ekonomi dan aktivitas pelakunya dapat diterima dalam "pergaulan ekonomi dunia" (Tri Budiyono, 2006) yang semakin menglobal.

Arus globalisasi juga memaksa peran pembangunan ekonomi Dunia Ketiga untuk lebih maju. Disamping itu, sumber daya alam yang dimiliki akan sangat berperan dalam melakukan pembangunan ekonomi, tinggal bagaimana manajemen sumber daya manusia yang dimiliki dapat melakukan pengelolaan terhadap aset produktif yang dapat mendukung pembangunan ekonomi setiap negara.

Fenomena arus globalisasi yang paling nyata, bagaimana negara-negara yang sedang berkembang pada Dunia Ketiga akan menjadi target kepentingan ekonomi negara adikuasa. Belum lagi, masalah 'gap' (kesenjangan) yang semakin melebar antara negara-negara berkembang dan miskin dengan negaranegara maju maupun dengan Transnational Corporation (TNC). Upaya 
Available online at: http://ejournal.unpas.ac.id/index.php/litigasi

Litigasi, Vol. 16(1), 2015, 2741-2780

DOI: http://dx.doi.org/10.23969/litigasi.v16i1.52

penghapusan kemiskinan (Poverty Alleviation) sebagaimana banyak dinyatakan secara retorik oleh Bank Dunia dan International Monetary Fund (IMF) kenyataannya hanyalah sikap mengelabui publik (kebohongan publik) secara terang-terangan, mengapa demikian? karena, dalam kenyataannya arah dan tujuan globalisasi dengan arah tujuan penghapusan kemiskinan sangatlah bertolak belakang, bukan saja bertolak belakang, tetapi juga berlawanan secara mendasar (Hasnati, 2004).

Globalisasi adalah mengenai pembukaan pasar seluas luasnya di seluruh dunia melalui berbagai instrumen termasuk Bank Dunia, IMF, MNC, TNC, WTO, dan lembaga sejenis lainya, dan "PASAR" tidak pernah memikirkan aspek sosial termasuk aspek perubahan pengaturan sumber daya manusia dan kecenderungannya justru hanya pada agenda penghapusan kemiskinan, penciptaan pasar untuk bagaimana menghasilkan profit dan profit, bukti paling jelas adalah liberalisasi sektor keuangan oleh IMF dan Bank Dunia pada tahun 1980an yang kini menjadi sebab utama krisis ekonomi, pelarian modal keluar negeri, serta beban utang meningkat tajam dan volatilitas keuangan tidak berkesudahan yang membangkrutkan bangsa-bangsa negara berkembang dan miskin hanya dalam hitungan hari (Hasnati, 2004).

Kemudian dari regulasi dan berbagai kenyataan untuk memperjelas fakta permasalahan. Maka, berikut sederet masa depan pembangunan ekonomi Dunia Ketiga yang menjadi korban globalisasi hukum yang menyengsarakan, diantaranya Venezuela dengan krisis ekonominya yang terjadi akibat dari

Copyright @ C 2015, LITIGASI, p-ISSN: 0853-7100; e-ISSN: 2442-2274 
Available online at: http://ejournal.unpas.ac.id/index.php/litigasi

Litigasi, Vol. 16(1), 2015, 2741-2780

DOI: http://dx.doi.org/10.23969/litigasi.v16i1.52

masuknya kepentingan globalisasi dengan alasan pasar bebas dan "Tangan Tuhan" atas mekanisme pasar yang mengaturnya. Krisis Venezuela terjadi sebab salah satu produsen terbesar minyak dunia ini dikuasai oleh perusahaan minyak Amerika, dan negara-negara Eropa. Seharusnya negara yang memiliki jutaan bahkan milyaran barel minyak ini harus lebih sejahtera, ternyata $80 \%$ penduduknya adalah masyarakat miskin, dan Hugo Chaves berpendapat bahwa kemakmuran akan dapat tercapai apabila perusahaan minyak dikelola sendiri bukan dikelola oleh pihak asing (Faisal Basri, 2005).

Tidak jauh dari Venezuela negara tetangganya Meksiko juga mengalami hal yang sama barang kali lebih parah, IMF dan Bank Dunia mengatur kemudahan investasi lewat penanaman modal asing $100 \%$ penguasaan dan monopoli HAKI (Hak Atas Kekayaan Intelektual). Dalam hal ini terkait dengan perdagangan dunia, yaitu berupa memberikan hak istimewa bagi individu atau perusahaan atas karya ciptanya, dalam bentuk Paten, Merk dan Hak Cipta, maka berbagai barang temuan dapat di kuasai siapa saja yang mendaftarkan terlebih dahulu, syaratnya merupakan temuan baru, mengandung langkah inovatif dan dapat diterapkan dalam industri (produksi massal). Sehingga teknologi dapat dikuasai terus menerus serta berbagai kemudahan untuk menguasai negara dalam berbagai sektor terutama barang publik. Semua kemudahan tersebut dan penghapusan atas berbagai hambatan usaha disuatu negara akan semakin memperbesar (TNC) dan membuatnya sebagai penguasa dunia yang sebenarnya (Faisal Basri, 2005). Globalisasi dalam dekade 
Available online at: http://ejournal.unpas.ac.id/index.php/litigasi

Litigasi, Vol. 16(1), 2015, 2741-2780

DOI: http://dx.doi.org/10.23969/litigasi.v16i1.52

terakhir ini tidak saja menjadi konsep ilmu pengetahuan sosial dan ekonomi, tetapi juga telah menjadi jargon politik, ideologi pemerintahan (rezim), dan hiasan bibir masyarakat awam di seluruh dunia. Teknologi informasi dan media elektronik dinilai sebagai simbol pelopor yang mengintegrasikan seluruh sistem dunia, baik dalam aspek sosial, budaya, ekonomi dan keuangan. Globalisasi bukanlah sesuatu yang baru, semangat pencerahan eropa di abad pertengahan yang mendorong pencarian dunia baru bisa dikategorikan sebagai arus globalisasi. Revolusi industri dan transportasi di abad XVIII juga merupakan pendorong tren globalisasi, yang membedakannya dengan arus globalisasi yang terjadi dua-tiga dekade belakangan ini adalah kecepatan dan jangkauannya. Selanjutnya, interaksi dan transaksi antara individu dan negara-negara yang berbeda akan menghasilkan konsekuensi politik, sosial, dan budaya pada tingkat dan intensitas yang berbeda pula. Masuknya Indonesia dalam proses globalisasi pada saat ini ditandai oleh serangkaian kebijakan yang diarahkan untuk membuka ekonomi domestik dalam rangka memperluas serta memperdalam integrasi dengan pasar internasional. Sangat menarik apa yang dikemukakan oleh Joseph E. Stiglitz, peraih hadiah Nobel Ekonomi tahun 2001 yang menyatakan bahwa "Globalisasi sendiri sebenarnya tidak begitu baik atau buruk, la memiliki kekuatan untuk melakukan kebaikan yang besar, dan bagi negara-negara di Asia Timur yang telah menerima globalisasi dengan persyaratan mereka sendiri, dengan kecepatan mereka sendiri, globalisasi memberikan manfaat yang besar, walaupun ada kemunduran akibat krisis 
Available online at: http://ejournal.unpas.ac.id/index.php/litigasi

Litigasi, Vol. 16(1), 2015, 2741-2780

DOI: http://dx.doi.org/10.23969/litigasi.v16i1.52

1997".

Dinegara kita pun tidak jauh dari apa yang terjadi pada negara-negara sedang berkembang lainnya, memasuki dasawarsa 1980 an kecenderungan ekonomi Indonesia semakin terintegrasi kepada ekonomi global. Perlu diketahui banyak kejadian kasus globalisasi yang kemudian menghancurkan baik dari segi kedaulatan nasional, hukum, dan jutaan rakyat Indonesia. Krisis yang berlangsung hingga saat ini adalah gambaran bahwa Indonesia merupakan korban terparah globalisasi.

Kasus ini tidak pernah diakui IMF dan Bank Dunia, dan para ekonomi liberal yang selalu menyalahkan kepada pemerintah dan negara bersangkutan, baik dari KKN (Korupsi, Kolusi, Nepotisme), Bad Governance dan lainya; karena hendak menutupi kepentingan mereka yang sebenarnya, dan ada berbagai hal lain semacam liberalisasi ekonomi dan kapitalisme global yang dipraktikan di Indonesia sebagai agenda besar deregulasi pelicin globalisai.

Berangkat dari kegagalan dan dampak globalisasi maka ada satu hal yang menjadi perhatian bersama yaitu, berupa runtuhlah teori ekonomi sebab bila dilihat dari awal mulai globalisasi yang merupakan perasan dasar dari teori Adam Smith (5 Juni 1723-Juli 1790) dengan bukunya "An Inquiry into the nature and couses of the wealth of nations" dan biasa disingkat dengan wealth of nation yang merupakan buku pertama tentang perekonomian modern dan merupakan dasar perdagangan bebas serta kapitalisme (Hasnati,

Copyright @ $\odot$ 2015, LITIGASI, p-ISSN: 0853-7100; e-ISSN: 2442-2274 
Available online at: http://ejournal.unpas.ac.id/index.php/litigasi

Litigasi, Vol. 16(1), 2015, 2741-2780

DOI: http://dx.doi.org/10.23969/litigasi.v16i1.52

2004).

Pendekatan yang dijelaskan arus globalisasi pada aspek pembangunan ekonomi Dunia Ketiga terkesan hanya menciptakan ruang eksploitasi tak terhenti. Serta akan menjadikan dunia matematis ekonomis dan tidak dapat pula menjelaskan sebagian dunia yang sudah global. Padahal sudah sama-sama kita ketahui ilmu ekonomi merupakan ilmu sosial yang berangkat dari realitas sosial bukan fisika atau aljabar yang serba pasti ditambah dengan pandangan teori ekonomi yang kausalitas (sebab-akibat) misalnya, jika pemerintah menurunkan tingkat suku bunga dan berharap dapat merangsang perekonomian, dengan maksud bisnis dapat meminjam uang dan membuat investasi modal.

Sebagaimana yang sudah diuraikan sebelumnya, globalisasi merupakan proyek normatif yang dibalut melalui teori ekonomi dengan tujuan membentuk tatanan masyarakat yang sesuai dengan logika pasar. Bangunan dasar globalisasi ini, menurut Bourdieu, tidak lebih sebagai sebuah fiksi matematika murni yang didasarkan pada sebuah abstraksi luhur mengenai realitas. Bentuk abstraksi ini dibangun konsepsi rasionalitas yang bercorak individual. Rasionalitas individual, seperti halnya paradigma neoklasik, memandang individu-individu dalam rangka memaksimumkan utilitas mereka melalui pilihan sarana yang terbaik guna melayani tujuan-tujuan meraka. Dengan kata lain, individu-individu adalah unit-unit yang dapat mengambil keputusan sendiri secara rasional dan otonom (Ahmad Erani Yustika, 2002).

Copyright @ C 2015, LITIGASI, p-ISSN: 0853-7100; e-ISSN: 2442-2274 
Available online at: http://ejournal.unpas.ac.id/index.php/litigasi

Litigasi, Vol. 16(1), 2015, 2741-2780

DOI: http://dx.doi.org/10.23969/litigasi.v16i1.52

Globalisasi merupakan sebuah tatanan rezim diskursif yang koheren, yang mampu megkonstruksi pemahaman sosial mengenai otoritas. Atas nama program pengetahuan ilmiah, globalisasi mengubah dirinya menjadi program politik untuk bertindak dan selanjutnya menerapkan makna hegemonik terhadap tatanan dunia. Sebagai proyek politik, globalisasi menuntun dunia untuk mencapai kesejahteraan universal berlandaskan pada utopia pasar bebas.

Singkatnya, globalisasi secara canggih mampu menggabungkan berbagai modal yang dikuasainya (ekonomi, politik, militer, sosial, dan pengetahuan tekhnologi) untuk kemudian membanguan kekuasaan dalam rangka memonopoli pemahaman atas kemajuan, pertumbuhan, dan kesejahteraan. Sehingga masa depan pembangunan ekonomi Dunia Ketiga hanya menjadi target pasar negara adikuasa melalui mekanisme pasar dan perdagangan internasional sebagai bentuk paket arus globalisasi.

Pertanyaannya kemudian, apakah masih ada jalan untuk menyelamatkan masa depan pembangunan ekonomi negara-negara Dunia Ketiga? Tentunya tulisan ini berangkat dari gagasan awal bahwa perlu adanya mekanisme hukum yang progresif dalam memetakan pembangunan ekonomi yang juga tidak mengeyampingkan nilai-nilai kemanusiaan. Artinya disamping faktor ekonomi secara murni, perlu kiranya instrumen hukum sebagai regulasi dapat berfungsi lebih responsif terhadap hak-hak dasar masyarakat dalam melakukan pembangunan ekonomi pada setiap negara, khususnya di Indonesia.

Copyright $\odot$ 2015, LITIGASI, p-ISSN: 0853-7100; e-ISSN: 2442-2274 
Available online at: http://ejournal.unpas.ac.id/index.php/litigasi

Litigasi, Vol. 16(1), 2015, 2741-2780

DOI: http://dx.doi.org/10.23969/litigasi.v16i1.52

A.F.K. Organski menyatakan bahwa negara-negara yang sekarang ini disebut negara modern menempuh pembangunanannya melalui tiga tahap pembangunan, yaitu unifikasi (unification), industrialisasi (industriali-zation), dan negara kesejahteraan (social welfare). Pada tingkat pertama, yang menjadi masalah berat adalah bagaimana mencapai integrasi politik untuk menciptakan persatuan dan kesatuan nasional. Tingkat kedua, perjuangan untuk pembangunan ekonomi dan modernisasi politik. Akhirnya dalam tingkat ketiga, tugas negara yang terutama adalah melindungi rakyat dari sisi negatif industrialisasi, membetulkan kesalahan pada tahap sebelumnya, dengan menekankan kesejahteraan masyarakat. Tingkat-tingkat tersebut dilalui secara berurutan (consecutive) dan memakan waktu relatif lama. Persatuan nasional adalah prasyarat untuk memasuki tahap industrialisasi, industrialisasi merupakan jalan untuk mencapai negara kesejahteraan. Pada dasarnya setiap kegiatan atau aktivitas manusia perlu diatur oleh suatu instrumen yang disebut sebagai hukum. Hukum disini direduksi pengertiannya menjadi perundangundangan yang dibuat dan dilaksanakan oleh negara. Cita-cita hukum nasional merupakan satu hal yang ingin dicapai dalam pengertian penerapan, perwujudan, dan pelaksanaan nilai-nilai tertentu di dalam tata kehidupan bernegara dan bermasyarakat yang berasaskan Pancasila dan berdasarkan Undang-Undang Dasar 1945. Khusus dalam bidang kehidupan dan kegiatan ekonomi pada umumnya dan dalam rangka menyongsong masyarakat global, cita hukum nasional sangat membutuhkan kajian dan pengembangan yang lebih

Copyright @ C 2015, LITIGASI, p-ISSN: 0853-7100; e-ISSN: 2442-2274 
Available online at: http://ejournal.unpas.ac.id/index.php/litigasi

Litigasi, Vol. 16(1), 2015, 2741-2780

DOI: http://dx.doi.org/10.23969/litigasi.v16i1.52

serius agar mampu turut serta dalam tata kehidupan ekonomi global dengan aman, dalam pengertian tidak merugikan dan dirugikan oleh pihak-pihak lain.

Lembaga hukum adalah salah satu di antara lembaga/pranata-pranata sosial, seperti juga halnya keluarga, agama, ekonomi, perang atau lainnya. Hukum bagaimanapun sangat dibutuhkan untuk mengatur kehidupan bermasyarakat di dalam segala aspeknya, baik dalam kehidupan sosial, politik, budaya, pendidikan, dan yang tak kalah penting adalah fungsinya atau peranannya dalam mengatur kegiatan ekonomi. Dalam kegiatan ekonomi inilah justru hukum sangat diperlukan karena sumber-sumber ekonomi yang terbatas disatu pihak dan tidak terbatasnya permintaan atau kebutuhan akan sumber ekonomi dilain pihak, sehingga konflik antara sesama warga dalam memperebutkan sumber-sumber ekonomi tersebut akan sering terjadi. Berdasarkan pengalaman sejarah, peranan hukum tersebut haruslah terukur sehingga tidak mematikan inisiatif dan daya kreasi manusia yang menjadi daya dorong utama dalam pembangunan ekonomi. Tuntutan agar hukum mampu berinteraksi serta mengakomodir kebutuhan dan perkembangan ekonomi dengan prinsip efisiensinya merupakan fenomena yang harus segera ditindaklanjuti apabila tidak ingin terjadi kepincangan antara laju gerak ekonomi yang dinamis dengan mandeknya perangkat hukum. Di samping itu ahli hukum juga diminta peranannya dalam konsep pembangunan, yaitu untuk menempatkan hukum sebagai lembaga (agent) modernisasi dan bahwa hukum dibuat untuk membangun masyarakat (social engineering).

Copyright @ C 2015, LITIGASI, p-ISSN: 0853-7100; e-ISSN: 2442-2274 
Available online at: http://ejournal.unpas.ac.id/index.php/litigasi

Litigasi, Vol. 16(1), 2015, 2741-2780

DOI: http://dx.doi.org/10.23969/litigasi.v16i1.52

Perubahan tatanan dunia saat ini ditandai oleh perkembangan teknologi yang memungkinkan komunikasi dan informasi antara masyarakat internasional menjadi sangat mudah, dan hukum internasional saat ini bercirikan hukum yang harmonis atau setidak-tidaknya hukum transnasional. Harmonisasi hukum di sini diartikan bahwa hukum internasional dipengaruhi hukum nasional dan hukum nasional juga dipengaruhi hukum internasional. Dalam proses harmonisasi hukum, dimana hukum internasional mempengaruhi hukum nasional, berarti negara nasional harus membuat aturan-aturan nasional yang mendorong realisasi kesepakatan guna mencapai tujuan bersama. Sebagai contoh dalam bidang perdagangan internasional, ketentuan-ketentuan perdagangan internasional dalam rangka World Trade Organization (WTO) telah mendorong negara-negara membuat aturan-aturan nasional sebagai tindak lanjut penerapan ketentuan tersebut dalam suasana nasional. Sebagai akibat globalisasi dan peningkatan pergaulan dan perdagangan internasional, cukup banyak peraturan-peraturan hukum asing atau yang bersifat internasional akan juga dituangkan ke dalam perundang-undangan nasional, misalnya di dalam hal surat-surat berharga, pasar modal, kejahatan komputer, dan sebagainya. Terutama kaidah-kaidah hukum yang bersifat transnasional lebih cepat akan dapat diterima sebagai hukum nasional, karena kaedahkaedah hukum transnasional itu merupakan aturan permainan dalam komunikasi dan perekonomian internasional dan global. Akibatnya semakin memasuki abad XXI, semakin hukum nasional Indonesia akan memperlihatkan

Copyright $\odot$ 2015, LITIGASI, p-ISSN: 0853-7100; e-ISSN: 2442-2274 
Available online at: http://ejournal.unpas.ac.id/index.php/litigasi

Litigasi, Vol. 16(1), 2015, 2741-2780

DOI: http://dx.doi.org/10.23969/litigasi.v16i1.52

sifat yang lebih transnasional, sehingga perbedaan-perbedaan dengan sistem hukum lain akan semakin berkurang.

C. Pengaruh Globalisasi Ekonomi dan Hukum Ekonomi Internasional dalam Pembangunan Hukum Ekonomi di Indonesia.

Pembangunan hukum adalah suatu pekerjaan yang sama tuanya dengan pekerjaan pembangunan negara dan bangsa (Gunarto Suhardi, 2002). Hadirnya undang-undang sebagai hukum tertulis melalui perundang-undangan dan dalam proses peradilan sebagai yurisprudensi (judge made law) juga telah lama dikenal dalam dunia hukum, demikian pula halnya dengan bagian dari hukum Indonesia yang saat ini semakin penting dan berpengaruh, yaitu hukum ekonomi Indonesia yang daya berlakunya di samping dalam lingkup nasional juga internasional. Relevansi hukum ekonomi semakin menonjol sejak lintas niaga masuk dalam dunia tanpa batas atau globalisasi ekonomi. Bagi Indonesia, tepatnya setelah meratifikasi persetujuan internasional di bidang perdagangan dalam suatu organisasi internasional yang dikenal dengan World Trade Organization (WTO), karena dengan demikian Indonesia harus mematuhi segala ketentuan yang berlaku bagi semua negara anggota WTO dengan segala konsekuensinya.

Realita ini menempatkan Indonesia untuk benar-benar dan bersungguhsungguh "mengikuti dan mengembangkan" hukum ekonomi internasional, terutama dalam pelaksanaannya atau penegakkan hukumnya, dimana semua

Copyright @ C 2015, LITIGASI, p-ISSN: 0853-7100; e-ISSN: 2442-2274 
Available online at: http://ejournal.unpas.ac.id/index.php/litigasi

Litigasi, Vol. 16(1), 2015, 2741-2780

DOI: http://dx.doi.org/10.23969/litigasi.v16i1.52

penegak hukum dan pelaku hukum dalam lintas bisnis nasional dan internasional. Hal ini berarti kekeliruan dalam pengelolaannya akan berakibat dirugikannya Indonesia dalam perdagangan internasional atau perdagangan bebas, bahkan dampaknya tidak hanya menyangkut para pihak dalam perjanjian bisnis internasional, melainkan juga rakyat Indonesia secara keseluruhan.

Menjawab dan mengantisipasi dampak perdagangan internasional abad XXI, tidak ada jalan lain kecuali harus menempatkan "Manajemen Penegakkan Hukum Bisnis Internasional" sebagai misi strategis dalam mewujudkan ketahanan ekonomi nasional di tengah globalisasi ekonomi yang sudah dan sedang berlangsung akhir-akhir ini (Sumantoro, 1986). Semakin baik dalam suatu negara hukum itu berfungsi, maka semakin tinggi tingkat kepastian hukum nyata. Sebaliknya, bila suatu negara tidak memiliki sistem hukum yang berfungsi secara otonom, maka semakin kecil pula tingkat kepastian hukumnya (T, Mulya Lubis, 1986). Perkembangan dalam teknologi dan pola kegiatan ekonomi membuat masyarakat di dunia semakin saling bersentuhan, saling membutuhkan, dan saling menentukan nasib satu sama lain, tetapi juga saling bersaing. Hal ini secara dramatis terutama terlihat dalam kegiatan perdagangan dunia, baik di bidang barang-barang (trade in goods), maupun di bidang jasa (trade in services). Saling keterkaitan ini memerlukan adanya kesepakatan mengenai aturan main yang berlaku. Aturan main yang diterapkan untuk perdagangan internasional adalah aturan main yang berkembang dalam sistem

Copyright @ C 2015, LITIGASI, p-ISSN: 0853-7100; e-ISSN: 2442-2274 
Available online at: http://ejournal.unpas.ac.id/index.php/litigasi

Litigasi, Vol. 16(1), 2015, 2741-2780

DOI: http://dx.doi.org/10.23969/litigasi.v16i1.52

GATT/WTO. Manakala ekonomi menjadi terintegrasi, harmonisasi hukum mengikutinya. Terbentuknya WTO (World Trade Organization) telah didahului oleh terbentuknya blok-blok ekonomi regional seperti Masyarakat Eropa, NAFTA, AFTA dan APEC. Tidak ada kontradiksi antara regionalisasi dan globalisasi perdagangan. Sebaliknya integrasi ekonomi global mengharuskan terciptanya blok-blok perdagangan baru. Berdagang dengan WTO dan kerjasama ekonomi regional berarti mengembangkan institusi yang demokratis, memperbaharui mekanisme pasar, dan memfungsikan sistem hukum.

Perkembangan yang mandiri dari perusahaan multinasional kerap kali diramalkan sebagai perkembangan suatu badan yang benar-benar tanpa kebangsaan, dan benar-benar mandiri. Peradaban dunia yang kemudian menjadi hukum internasional turut mempengaruhi pembangunan hukum nasional dan sistem perekonomian negara berkembang. Globalisasi ekonomi sekarang ini adalah manifestasi yang baru dari pembangunan kapitalisme sebagai sistem ekonomi internasional. Sebagai suatu ideologi, globalism menawarkan seperangkat ide, konsep, keyakinan, norma dan tata nilai mengenai tatanan masyarakat dunia yang dicita-citakan serta bagaimana cara untuk mewujudkannya (Sri Redjeki Hartono, 2000).

Bagaimanapun karakteristik dan hambatannya, globalisasi ekonomi menimbulkan akibat yang besar sekali pada bidang hukum, globalisasi ekonomi juga menyebabkan terjadinya globalisasi hukum. Globalisasi hukum tersebut

Copyright @ C 2015, LITIGASI, p-ISSN: 0853-7100; e-ISSN: 2442-2274 
Available online at: http://ejournal.unpas.ac.id/index.php/litigasi

Litigasi, Vol. 16(1), 2015, 2741-2780

DOI: http://dx.doi.org/10.23969/litigasi.v16i1.52

tidak hanya didasarkan kesepakatan internasional antar bangsa, tetapi juga pemahaman tradisi hukum dan budaya antara barat dan timur. Globalisasi di bidang kontrak-kontrak bisnis internasional sudah lama terjadi, karena negaranegara maju membawa transaksi baru ke negara berkembang, maka mitra kerja mereka dari negara-negara berkembang akan menerima model-model kontrak bisnis internasional tersebut, dapat disebabkan karena sebelumnya tidak mengenal model tersebut, dapat juga karena posisi tawar (bargainig position) yang lemah. Oleh karena itu tidak mengherankan, perjanjian patungan (joint venture), perjanjian waralaba (franchise), perjanjian lisensi (license), perjanjian keagenan (agence), memiliki format dan substansi yang hampir sama diberbagai negara. Konsultan hukum suatu negara dengan mudah mengerjakan perjanjian-perjanjian semacam itu di negara-negara lain, persamaan ketentuanketentuan hukum di berbagai negara bisa juga terjadi karena suatu negara mengikuti model negara maju berkaitan dengan institusi-institusi hukum untuk mendapatkan akumulasi modal. Undang-undang Perseroan Terbatas diberbagai negara, baik dari negara-negara Civil Law maupun Common Law berisikan substansi yang serupa. Begitu juga dengan peraturan pasar modal, dimana saja tidak berbeda, satu sama lain. Hal ini terjadi karena dana yang mengalir ke pasar-pasar tersebut tidak lagi terikat benar dengan waktu dan batas-batas negara. Tuntutan keterbukaan (transparency) yang semakin besar, berkembangnya kejahatan internasional dalam pencucian uang (money laundering) dan insider trading mendorong kerjasama internasional.

Copyright @ C 2015, LITIGASI, p-ISSN: 0853-7100; e-ISSN: 2442-2274 
Available online at: http://ejournal.unpas.ac.id/index.php/litigasi

Litigasi, Vol. 16(1), 2015, 2741-2780

DOI: http://dx.doi.org/10.23969/litigasi.v16i1.52

Dibalik usaha keras menciptakan globalisasi hukum, tidak ada jaminan bahwa hukum tersebut akan memberikan hasil yang sama di semua tempat. Hal tersebut disebabkan oleh perbedaan politik, ekonomi dan budaya. Hukum itu tidak sama dengan kuda, orang tidak akan menamakan keledai atau zebra adalah kuda, walau bentuknya hampir sama, kuda adalah kuda. Hukum tidak demikian, apa yang disebut hukum itu tergantung kepada persepsi masyarakatnya. Friedman, menyatakan bahwa tegaknya peraturan-peraturan hukum tergantung kepada budaya hukum masyarakatnya. Budaya hukum masyarakat tergantung kepada budaya hukum anggota-anggotanya yang dipengaruhi oleh latar belakang pendidikan, lingkungan budaya, posisi atau kedudukan, bahkan kepentingan-kepentingan. Dalam menghadapi hal yang demikian itu perlu "check and balance" dalam bernegara. "check and balance" hanya bisa dicapai dengan parlemen yang kuat, pengadilan yang mandiri, dan partisipasi masyarakat melalui lembaga-lembaganya. Dalam hal tersebut, khususnya dalam masalah pengawasan dan Law Enforcement, dua hal yang merupakan komponen yang tak terpisahkan dari sistim rule of law. Tidak akan ada law enforcement kalau tidak ada sistim pengawasan dan tidak akan ada rule of law kalau tidak ada law enforcement yang memadai.

E.C.W. Wade dan Godfrey Philips menyatakan tiga konsep mengenai "Rule of Law" (Sri Redjeki Hartono, 2000) yaitu The Rule of Law mendahulukan hukum dan ketertiban dalam masyarakat yang dalam pandangan tradisi barat lahir dari alam demokrasi; The Rule of Law

Copyright $\odot$ 2015, LITIGASI, p-ISSN: 0853-7100; e-ISSN: 2442-2274 
Available online at: http://ejournal.unpas.ac.id/index.php/litigasi

Litigasi, Vol. 16(1), 2015, 2741-2780

DOI: http://dx.doi.org/10.23969/litigasi.v16i1.52

menunjukkan suatu doktrin hukum bahwa pemerintahan harus dilaksanakan sesuai dengan hukum; The Rule of Law menunjukkan suatu kerangka pikir politik yang harus diperinci oleh peraturan-peraturan hukum baik substantif maupun hukum acara. Berbagai unsur dari pengertian Rule of Law tersebut haruslah dilaksanakan secara keseluruhan, bukan sepotong-sepotong, dan dalam waktu bersamaan. Pengecualian dan penangguhan salah satu unsurnya akan merusak keseluruhan sistim.

Berdasarkan tataran ide normatif dalam GBHN, hukum secara tegas diletakkan sebagai pendorong pembangunan, khususnya terhadap pertumbuhan ekonomi. Berdasarkan amanat ini, maka hukum tentu sangat memerlukan dukungan yang terdiri dari personalia yang profesional dan beretika, organisasi yang kapabel dan berdaya guna, serta peradilan yang bebas dan berhasil guna. Semuanya ini adalah sebagian prasyarat konsepsional yang paling di butuhkan dalam konteks kekinian Indonesia. Sayangnya, ketika memasuki tataran implementasi-sosiologis, selain tampak dengan jelas berbagai hal yang menggembirakan, terlihat pula adanya "peminggiran" peran hukum dalam upaya mencapai kemajuan bangsa yang telah dicanangkan. Dalam berbagai arena pergulatan hidup masyarakat, terkadang dengan mudah dilihat atau dirasakan kemandulan peran dan fungsi hukum.

Copyright @ $\odot$ 2015, LITIGASI, p-ISSN: 0853-7100; e-ISSN: 2442-2274 
Available online at: http://ejournal.unpas.ac.id/index.php/litigasi

Litigasi, Vol. 16(1), 2015, 2741-2780

DOI: http://dx.doi.org/10.23969/litigasi.v16i1.52

D. Peran Hukum Sebagai Bentuk Perwujudan Instrumen Regulasi Dalam Pembangunan Ekonomi Indonesia

Secara konstitusional sistem pembangunan ekonomi Indonesia didasarkan pada prinsip keseimbangan, kepastian dan keadilan yang kemudian semua itu dikelola dan diatur oleh negara. Dengan pemahaman seperti itu bahwa bangsa ini mempunyai cita-cita bersama untuk mendapatkan hak kedaulatan ekonomi dalam hidup berbangsa dan bernegara. Bertolak dari itu, hak kedaulatan ekonomi secara eksplisit dapat dilihat pada Pasal 33 ayat 1, 2, dan 3 UUD 1945 yang secara utuh dan menyeluruh dapat dijadikan orientasi sistem perekonomian Indonesia. Amanat konstitusi ini dapat dipahami tidak hanya dimaksudkan sebagai landasan yuridis sistem perekonomian Indonesia, melainkan sekaligus sebagai dasar bagi penyelenggaraan demokrasi pembangunan ekonomi Indonesia.

Ketika melihat konsep dasar dari Pasal 33 ayat 1, 2 dan 3 UUD 1945 dalam kerangka hukum progresif, sejatinya masih berada pada optik sosiologis bahwa hukum diperuntukkan melayani kepentingan masyarakat. Seperti halnya yang disebutkan dalam amanat konstitusi tersebut "bahwa bumi, air dan kekayaan alam beserta cabang-cabang produksi yang menguasai hajat hidup orang banyak dikuasai oleh negara dan dipergunakan sebesar - besarnya untuk kemakmuran rakyat. Pada hakikatnya gagasan ini adalah suatu proses memberi bentuk terhadap sejumlah keinginan hak kedaulatan ekonomi bangsa Indonesia. Dengan demikian yang lebih dikedepankan adalah membuat suatu

Copyright @ C 2015, LITIGASI, p-ISSN: 0853-7100; e-ISSN: 2442-2274 
Available online at: http://ejournal.unpas.ac.id/index.php/litigasi

Litigasi, Vol. 16(1), 2015, 2741-2780

DOI: http://dx.doi.org/10.23969/litigasi.v16i1.52

bangunan perundang-undangan yang memiliki orientasi pada kebijakan pembangunan ekonomi dengan struktur rasional dan bertolak dari potret struktur sosial masyarakat. Paradigma yang demikian itu tentunya dalam menghadapi masalah, tanpa meninggalkan subjek akar rumput masalah.

Terlepas dari kejelasan bentuk serta tujuan sistem pembangunan ekonomi Indonesia tersebut, suatu hal kiranya perlu ditegaskan disini. Dengan ditetapkannya Pasal 33 ayat 1, 2 dan 3 UUD 1945 sebagai konsep dasar tujuan dari pembangunan ekonomi Indonesia, hal itu tidak serta merta merupakan penolakan terhadap ketidakhadiran investor asing dengan melakukan aktivitas ekonomi melalui perusahaan yang tidak berbentuk Badan Usaha Milik Negara (BUMN). Akan tetapi persoalannya kehadiran perusahaan asing yang melakukan eksplorasi maupun eksploitasi terhadap sumber daya alam yang dimiliki, justru membuat Pasal 33 UUD 1945 ini tidak lagi memiliki legitimasi kedaulatan ekonomi kerakyatan. Karena antara mewujudkan cita-cita demokratisasi pembangunan ekonomi yang berbasis kerakyatan berdasarkan amanat konstitusi, akan selalu bersitegang dengan realitas yang sampai sejauh ini perusahaan asing hanya mengeruk kekayaan alam kita, tanpa memberikan kontribusi secara seimbang dengan apa yang sudah menjadi hak bangsa ini. Tentu bangsa ini tidak selalu menutup mata, bagaimana bisa potret yang terjadi di papua, kekayaan alam yang berlimpah ruah, dan freport sebagai perusahaan asing dari Amerika Serikat yang melakukan eksploitasi terhadap kekayaan alam di papua hanya sekian persen saja hasil dari penambangan dapat

Copyright @ $\odot$ 2015, LITIGASI, p-ISSN: 0853-7100; e-ISSN: 2442-2274 
Available online at: http://ejournal.unpas.ac.id/index.php/litigasi

Litigasi, Vol. 16(1), 2015, 2741-2780

DOI: http://dx.doi.org/10.23969/litigasi.v16i1.52

dinikmati oleh rakyat papua. Terbukti fenomena busung lapar menjadi ancaman bagi rakyat papua, dan persoalan ini menjadi indikator kegagalan sistem pembangunan ekonomi saat ini.

Penggunaan instrument hukum progresif memiliki peran strategis untuk menyingkap dan melakukan perubahan-perubahan pada pengaturan dasar masyarakat dan konsepsi-konsepsi yang dimiliki anggota masyarakat tentang dirinya sendiri, hak, kewajiban, serta tanggungjawabnya terhadap negara. Pada saat yang sama, perubahan-perubahan ini akan membantu menafsirkan ulang transformasi tatanan hukum, dari negara hukum formal positivistik sebagai dasar dasar tatanan sosial, politik, dan ekonomi menuju negara hukum yang subtansial yang membahagiakan rakyatnya serta menjunjung tinggi terwujudnya negara kesejahteraan (welfare state) (Rachmad Safa'at, 2008).

IImu hukum progresif memperhatikan kesenjangan sosial yang terjadi dengan motif pembangunan ekonomi, dilakukan melalui sistem ekonomi neoliberalisme. Di balik prinsip-prinsip dasar dari sistem ekonomi neo-liberalisme, terlihat jelas bahwa antara faktor kerakusan manusia sebagai embrio munculnya paham positivisme hukum pada sektor sistem ekonomi tersebut, sesungguhnya merupakan mata rantai yang terkait erat di antara satu dengan lainnya. Kehadiran globalisasi sebagai proses kapitalisasi ekonomi liberal, tidak lain berakar pada perilaku manusia individu yang mengumbar nafsu keserakahan duniawi, dan tidak segan-segan mengorbankan kepentingan masyarakat keseluruhan (Satjipto Rahardjo, 1982).

Copyright @ C 2015, LITIGASI, p-ISSN: 0853-7100; e-ISSN: 2442-2274 
Available online at: http://ejournal.unpas.ac.id/index.php/litigasi

Litigasi, Vol. 16(1), 2015, 2741-2780

DOI: http://dx.doi.org/10.23969/litigasi.v16i1.52

Globalisasi telah memunculkan pembagian kekuasaan yang tidak merata dan tidak seimbang. Sebagian besar kekuasaan dalam pembuatan hukum maupun penegakan hukum berada di tangan para aktor globalisasi, sedangkan para pelaku ekonomi di negara-negara berkembang semakin memberikan tekanan ekonomi. Kondisi demikian itu memberikan bukti bahwa sistem perekonomian menjadi faktor pendorong terjadinya perlapisan sosial dalam skala global. Penumpukan kekuasaan di tangan para aktor globalisasi, berhubungan dengan penguasaan sumber - sumber daya alam dalam masyarakat (dunia). Dengan terjadinya perlapisan sosial, maka hukum pun sulit mempertahankan netralitasnya. Di sinilah Friedman menunjukkan bahwa perlapisan sosial merupakan kunci bagi penjelasan mengapa hukum itu bersifat diskriminatif, baik pada substansi maupun pelaksanaannya dalam menjalankan sistem pembangunan ekonomi global maupun nasional (Satjipto Rahardjo, 1982).

Kata kunci dalam gagasan hukum progresif adalah kesediaan untuk membebaskan diri dalam faham status quo. Ide tentang pembebasan diri tersebut berkaitan erat dengan faktor psikologis atau spirit yang ada dalam diri pelaku (aktor) hukum, yaitu keberanian (dare). Maksudnya faktor keberanian tersebut memperluas peta cara berhukum, yaitu yang tidak hanya mengedepankan aturan (rule), tetapi juga perilaku (behavior). Berhukum menjadi tidak hanya tekstual, melainkan juga melibatkan predisposisi personal. Pelaku hukum yang berani bukan sekedar pembicaraan atau sesuatu yang

Copyright $\odot$ 2015, LITIGASI, p-ISSN: 0853-7100; e-ISSN: 2442-2274 
Available online at: http://ejournal.unpas.ac.id/index.php/litigasi

Litigasi, Vol. 16(1), 2015, 2741-2780

DOI: http://dx.doi.org/10.23969/litigasi.v16i1.52

abstrak, melainkan sesuatu yang nyata ada dalam masyarakat (Satjipto Rahardjo, 2007).

Paradigma hukum progresif selalu mencerna perubahan yang terjadi dalam dinamika masyarakat. Dengan kualitas yang demikian itu, maka hukum progresif akan selalu gelisah melakukan pencarian dan pembebasan. Pencarian terus dilakukan, oleh karena memang hakikat ilmu itu adalah mencari kebenaran. Setidaknya paradigma hukum progresif memberikan jalan dengan berupa alternatif di tengah-tengah degradasi orientasi sistem pembangunan ekonomi Indonesia saat ini. Pertanyaannya, tindakan apakah yang perlu dilakukan secara mendasar dan sekaligus meletakkan dasar-dasar pelaksanaan pembangunan ekonomi Indonesia secara lebih berkeadilan, partisipatif dan berkesinambungan? Untuk itu peranan negara dalam politik pembangunan ekonomi Indonesia, sebagaimana diamanatkan oleh Pasal 33 ayat 1, 2 dan 3 UUD 1945, ditekankan pada segi membuat peraturan perundang-undangan guna mengatur jalannya pembangunan ekonomi yang berbasis kerakyatan. Tujuannya adalah untuk menjamin agar kemakmuran masyarakat senantiasa lebih diutamakan daripada kemakmuran orang seorang dan agar tampuk produksi tidak jatuh ke tangan orang seorang yang memungkinkan dilakukannya penindasan rakyat banyak oleh segelintir orang yang berkuasa.

Agenda pembangunan ekonomi kerakyatan yang diasumsikan sebagai agenda pembanguanan ekonomi progresif, didasarkan atas upaya terusmenerus menciptakan demokratisasi modal dengan penuh keseimbangan, 
Available online at: http://ejournal.unpas.ac.id/index.php/litigasi

Litigasi, Vol. 16(1), 2015, 2741-2780

DOI: http://dx.doi.org/10.23969/litigasi.v16i1.52

keadilan serta kepastian demi kesejahteraan sebesar-besarnya bagi kesejahteraan rakyat. Setidaknya terdapat empat agenda pembangunan ekonomi kerakyatan yang perlu segera dilakukan. Keempat agenda pembangunan ekonomi progresif tersebut, pertama, desentralisasi penguasaan sumber-sumber penerimaan negara kepada pemerintah daerah. Hal ini dapat dilakukan dengan melanjutkan reformasi fiskal (pembaruan Undang-Undang Perimbangan Keuangan Pusat Daerah, Undang-Undang Perpajakan, dan Undang-Undang Pajak dan Retribusi Daerah). Dengan catatan kebijakan pembaruan formulasi ini merupakan refleksi dari amanat konstitusi Pasal 33 ayat 1, 2 dan 3 UUD 1945 (Revirsond Baswir, 1999). Kedua, pembatasan penguasaan dan redistribusi pemilikan lahan pertanian kepada para petani penggarap. Selama ini, penguasaan lahan pertanian secara berlebihan dilakukan yang dilakukan oleh segelintir pejabat, konglomerat dan atau petani berdasi sebagaimana terjadi pada era Orde Baru harus segera diakhiri (Revirsond Baswir, 1999). Ketiga, penciptaan struktur dan mekanisme pasar yang menjamin berlangsungnya persaingan secara berkeadilan. Struktur dan mekanisme pasar yang menjamin berlangsungnya persaingan secara berkeadilan merupakan satu-satunya institusi yang dapat diandalkan untuk menghindari terjadinya konsentrasi ekonomi dan monopoli usaha di tangan segelintir pengusaha besar. Untuk itu, Undang-Undang Anti Monopoli harus lebih diupayakan secara optimal agar dapat menjamin terwujudnya lingkungan usaha yang transparan dan kompetitif. Kemudian yang keempat, penerapan

Copyright $\odot$ 2015, LITIGASI, p-ISSN: 0853-7100; e-ISSN: 2442-2274 
Available online at: http://ejournal.unpas.ac.id/index.php/litigasi

Litigasi, Vol. 16(1), 2015, 2741-2780

DOI: http://dx.doi.org/10.23969/litigasi.v16i1.52

sistem perpajakan yang bersifat progresif sebagai upaya untuk mempertahankan demokratisasi modal ditengah-tengah masyarakat. Selain itu, penerapan sistem perpajakan yang bersifat progresif ini juga diperlukan sebagai upaya untuk secara terus-menerus membentuk dana sosial bagi anggota masyarakat yang rentan. Dengan adanya sumber dana pasti bagi penyelenggaraan program perlindugan sosial maka tanggung jawab negara sebagai pemelihara fakir miskin dan anak-anak terlantar sebagaimana yag diamanatkan oleh konstitusi akan dapat dijalankan secara konsisten dan berkesinambungan.

Kenyataan tersebut memperlihatkan, bahwa konsep alternatif pembangunan ekonomi kerakyatan dengan langkah progresif yang mencoba mencari penyelesaian terhadap krisis pembangunan ekonomi yang terusmenerus terjadi di Indonesia, tampaknya masih merupakan konsep pinggiran yang masih belum dijalankan sepenuhnya. Konsep ini masih harus di perjuangkan secara gigih, dan mungkin akan memakan waktu yang lama sebelum pada akhirnya dapat dijalankan secara efektif.

Copyright @ 9 2015, LITIGASI, p-ISSN: 0853-7100; e-ISSN: 2442-2274 
Available online at: http://ejournal.unpas.ac.id/index.php/litigasi

Litigasi, Vol. 16(1), 2015, 2741-2780

DOI: http://dx.doi.org/10.23969/litigasi.v16i1.52

\section{SIMPULAN DAN SARAN}

\section{A. Simpulan}

1. Pembangunan ekonomi kerakyatan yang mendasari keempat agenda gagasan alternatif pembangunan ekonomi progresif tidak didasarkan pada paradigma sistem ekonomi neo-liberalisme, melainkan melalui paradigma sistem ekonomi progresif. Artinya, pelaksanaan pembangunan ekonomi Indonesia tidak lagi bertumpu pada dominasi pemerintah pusat dan perusahaan-perusahaan konglomerasi, melainkan dilakukan pada kekuatan pemerintah daerah, mekanisme pasar berbasis kerakyatan, usaha-usaha pertanian rakyat dan sistem perpajakan yang progresif. Diatas fondasi sistem pembangunan ekonomi progresif itulah selanjutnya, bangunan ekonomi Indonesia yang adil, partisipatif, dan berkesinambungan akan ditegakkan.

2. Rasanya tidaklah adil apabila melihat globalisasi dan liberalisasi ekonomi secara apriori, namun sebaliknya menerimanya dengan mentah-mentah begitu saja tanpa bersikap kritis juga bukan sikap yang bijaksana. Dengan berbagai akibat positif dan negatifnya, globalisasi ekonomi bukanlah sesuatu yang tidak dapat dikendalikan, diubah atau bahkan dihentikan. Salah satu langkahnya adalah dengan tetap memberikanv kewenangan kepada negara untuk melakukan fungsinya sebagai pengendali pasar melalui berbagai regulasi ekonomi, menyerahkan 
Available online at: http://ejournal.unpas.ac.id/index.php/litigasi

Litigasi, Vol. 16(1), 2015, 2741-2780

DOI: http://dx.doi.org/10.23969/litigasi.v16i1.52

sepenuhnya aktivitas ekonomi nasional pada mekanisme pasar yang diyakini sebagai "self regulating" justru akan menimbulkan ketidakadilan bagi banyak pihak di dalam negeri dan sebaliknya membuka peluang transnational untuk mengeksploitasi sumber-sumber daya ekonomi bangsa Indonesia.

3. Pelaksanaan roda pemerintahan dengan demokratis dan menggunakan hukum sebagai salah satu instrumen untuk merencanakan dan melaksanakan program pembangunan yang komprehensif, akan membawa negara ini menuju masyarakat dengan tingkat kesejahteraan yang di cita-citakan.

B. Saran

1. Pada tataran ide normatif dan $G B H N$, hukum secara tegas diletakan sebagai pendorong pembangunan, khususnya terhadap pertumbuhan ekonomi. Berdasarkan amanat ini, maka hukum tentu sangat memerlukan dukungan yang terdiri dari personalia yang profesional dan beretika, organisasi yang kapabel dan berdaya guna, serta peradilan yang bebas dan berhasil guna. Semuanya ini adalah sebagian prasyarat konsepsional yang paling dibutuhkan dalam konteks kekinian Indonesia.

Copyright @ C 2015, LITIGASI, p-ISSN: 0853-7100; e-ISSN: 2442-2274 
Available online at: http://ejournal.unpas.ac.id/index.php/litigasi

Litigasi, Vol. 16(1), 2015, 2741-2780

DOI: http://dx.doi.org/10.23969/litigasi.v16i1.52

2. Adanya sinkronisasi antara hukum dan ekonomi yang bernuansa ke Indonesiaan sehingga peran keduanya sangat vital dalam menghadapi globalisasi kedepannya dan diperlukan gagasan hukum progresif dalam menghadapi pembangunan ekonomi yang berbasis kerakyatan. 


\section{DAFTAR PUSTAKA}

Abdul Manan. 2006. Aspek-aspek Pengubah Hukum. Jakarta: Kencana.

Ahmad Erani Yustika. 2002. Pembangunan \& Krisis Memetakan Perekonomian Indonesia, Korupsi Kepresidenan. Jakarta: Grasindo.

Arief Budiman. 1995. Teori Pembangunan Dunia Ketiga. Jakarta: Gramedia Pustaka Utama.

Faisal Basri. 2005. Kita Harus Berubah. Jakarta: Kompas.

Gunarto Suhardi. 2002 Peranan Hukum Dalam Pembangunan Ekonomi. Yogyakarta: Universitas Atmajaya

Hikmahanto Juwana. 2001. Hukum Ekonomi \& Hukum Internasional. Jakarta: Lentera Hati.

Revirsond Baswir. 2004. Drama Ekonomi Indonesia Belajar dari Kegagalan Ekonomi Orde Baru. Yogyakarta: Kreasi Wacana.

Satjiptoa Rahardjo. 1982. IImu Hukum. Bandung: Alumni.

Sri Redjeki Hartono. 2002. Pembinaan Cita Hukum dan Asas-asas Hukum Nasional (Ditinjau dari Aspek Hukum Dagang dan Ekonomi) dalam Kapita Selekta Hukum Ekonomi, diedit oleh Husni Syawali dan Neni Sri Imaniyati. Bandung: Mandar Maju.

Sumantoro. 1986 Hukum Ekonomi. Jakarta: UI Press.

T. Mulya Lubis. ed. 1986. Peranan Hukum Dalam Perekonomian di Negara Berkembang. Jakarta: Yayasan Obor Indonesi. 
Available online at: http://ejournal.unpas.ac.id/index.php/litigasi

Litigasi, Vol. 16(1), 2015, 2741-2780

DOI: http://dx.doi.org/10.23969/litigasi.v16i1.52

\section{JURNAL}

Diana Halim Koentjoro. 2006. Penegakan Hukum dan Peraturan Ekonomi di Indonesia, Jurnal Gloria Juris, Volume 6, Nomor 2.

Hasnati. 2004. Perlunya Reformasi Hukum Pembangunan Ekonomi Indonesia, Jurnal Hukum Republika, Vol 4, No. 1.

Indra Afrita. 2005. Peranan Hukum Investasi dalam Pembangunan Ekonomi di Indonesia. Jurnal Hukum Republika. Volume 4. Nomor 2.

Rachmad Saf'at. 2008. Peranan Hukum Progresif Dalam Transformasi Sistem Ekonomi Nasional yang Berkeadilan Sosial. Jurnal Hukum Progresif. Volume 4. Nomor 1.

Satjipto Rahardjo. 2007. Arsenal Hukum Progresif. Jurnal Hukum Progresif. Volume 3. Nomor 1.

Tri Budiyono. 2006. Transplantasi Doktrin Pada UUPT dan Pengaruhnya terhadap GCG dan CSR. Jurnal Hukum dan Dinamika Masyarakat. Edisi April.

\section{MEDIA MASSA}

Revirsond Baswir. Pembangunan Kerakyatan Melalui Demokratisasi Pengelolaan SDA. Suara Pembaharuan, Jakarta, 19 Februari 1999. 
Available online at: http://ejournal.unpas.ac.id/index.php/litigasi

Litigasi, Vol. 16(1), 2015, 2741-2780

DOI: http://dx.doi.org/10.23969/litigasi.v16i1.52

\section{MAKALAH}

Thomos M, Franck. 1972, The new Development : Can American Law and Legal Institutions Help Developing Countries. Wisconsin Law Review No. 3. dalam Erman Rajagukguk. 2005. Hukum dan Pembangunan. Jilid I (Bahan Diskusi Program Magister Hukum). PascaSarjana FH UI.

Leonard J, Theberge dalam Erman Rajagukguk. 2005. Hukum dan Pembangunan. Jilid I (Bahan Diskusi Program Magister Hukum). Jakarta: PascaSarjana FH UI. 